\title{
Preparation and Application of Biochar from Brewery`s Spent Grain and Sewage Sludge
}

\author{
Zhang Yinxin ${ }^{1}$, Zhang $\mathrm{Jishi}^{2}$ and $\mathrm{Ma} \mathrm{Yi}^{*}, 1$ \\ ${ }^{I}$ School of Chemistry and Pharmaceutical Engineering, Qilu University of Technology, Jinan, 250353, P.R. China \\ ${ }^{2}$ School of Light Chemistry and Environment Engineering, Qilu University of Technology, Jinan, 250353, P.R. China
}

\begin{abstract}
Brewery`s spent grain (BSG) and sewage sludge (SS) were used as raw material at the temperature from $400^{\circ} \mathrm{C}$ to $700{ }^{\circ} \mathrm{C}$ and limited oxygen $\left(\mathrm{O}_{2}<5 \%\right)$ conditions to prepare biochar (BC). One aim is to examine the $\mathrm{BC}$ characterization prepared under different temperatures and various proportions of SS. Another aim is to find the optimum preparation conditions of $\mathrm{BC}$ for treating wastewater. Results showed $\mathrm{BC}$ had more obvious physical and chemical variation between $400^{\circ} \mathrm{C}$ and $500^{\circ} \mathrm{C}$ than temperature $600^{\circ} \mathrm{C}$ and $700^{\circ} \mathrm{C}$. pH was followed by $700^{\circ} \mathrm{C}>600^{\circ} \mathrm{C}>500^{\circ} \mathrm{C}$ $>400^{\circ} \mathrm{C}$ increased from 6.0 to 10.1. FT-IR results showed: BC rich in carboxyl and phenolic hydroxyl which were surface oxygen functional groups. Electron microscope scanning (EMS) analysis results indicated: when the temperature was $400^{\circ} \mathrm{C}$, the surface of $\mathrm{BC}$ formed tiny holes, but was fuzzy; with the pyrolysis temperature increasing, plug of the hole opened and walls became thinner. BC adsorption results showed: under same pyrolysis temperature, adsorption effects were best under the proportion of SS $80 \%$ for ammonia-nitrogen, 100\% for phosphorus-containing wastewater, and $10 \%$ for chromium (VI) wastewater. BC prepared under higher temperature had the better removal effect for wastewater.
\end{abstract}

Keywords: Brewery's spent grain, sewage sludge, biochar, characterization analysis, adsorption properties.

\section{INTRODUCTION}

Due to biochar preparation had widely raw material sources, relatively simple preparation process and excellent physical and chemical properties, it has become an ideal adsorption material. At present, a lot of researches focused on the adsorption property [1-3] by one kind raw material made biochar, however, studies about two or more raw material made biochar property were rarely reported. Brewery`s spent grain (BSG) and sewage sludge (SS) are two kinds of typical industrial waste. BSG is the rest material of brewery industrial while SS is the suspended substance in the sewage treatment plant formed after precipitation. There are many kinds of traditional processing methods for utilization BSG and SS. Due to BSG`s chemical composition, it can be of value as a raw material, such as food ingredient [4], energy production [5], charcoal production [6], as a brick component [7], paper manufacture [8] and etc.. As the constituents removed by effluent treatment, SS is by far the largest in volume waste, therefore, its handling methods and disposal techniques become a matter of great concern. $80 \%$ of the SS had not been disposed of properly. Because the disadvantages of the traditional treatment ways of SS, the waste problems were not radically solved, and it great potential environmental risk, it is put forward that resource utilization technique will be the main way of the final disposal of sludge.

\footnotetext{
*Address correspondence to this author at the School of Chemistry and Pharmaceutical Engineering, Qilu University of Technology, Jinan, PR, 250353, China; Tel: 15508665819; E-mail:mayiqlu@163.com
}

Biochar is residue of biomass pyrolysis generated under the condition of limited oxygen [9]. It had extensive source for biochar producing such as straw, grass, wood chips, livestock poultry dung, organic waste and sludge etc.. Due to its high porosity, large specific surface area and rich source of functional groups such as: carboxyl, negative charges, high charge density $[10,11]$ phenolic hydroxyl and carbonyl, quinonyl [12], biochar had good adsorption properties, and can be used as the adsorbent of pollutants in soil and water. Studies had shown that biochar can adsorb organic contaminants like PAHS, PCBS, PCDS, MCPA and pesticides via the surface adsorption and distribution adsorption [13], also can strongly adsorb metal ions such as $\mathrm{Hg}$ (II), $\mathrm{As}(\mathrm{III}), \mathrm{Cr}(\mathrm{VI}), \mathrm{Pb}(\mathrm{II})$ and $\mathrm{Cd}(\mathrm{II})$ in aqueous solution $[14,15]$. Moreover, biomass carbonization technology was recognized as one of the feasible technical measures to solve the problem of climate change, and has many advantages such as low cost of production ecological safety, no pollution. Moreover, the comprehensive utilization of biochar can solve the sustainable development, energy saving, environmental protection and management problems, and can help to build a low carbon high efficient economic development model, have a great significance for safeguarding national environmental, energy, food security.

Academics generally believe that raw materials and pyrolysis temperature were the most two significantly factors affected the biochar physical and chemical properties and environment function. In this paper we not only made full use of BSG and SS, but also depose sewage and achieved the purpose of using waste to treat waste. Moreover, various proportion of BSG and SS mixed for preparing biochar was 
rarely reported, and this work also had theoretical guidance meaning for the preparation of biochar.

\section{EXPERIMENTAL}

\subsection{Materials and Pre-treatment}

BSG was derived from the Brewing Beer Center in Qilu University of Technology, China. SS was collected from a municipal wastewater treatment plant in Jinan (China). The samples were all air-dried at room temperature and then crushed by a high-speed universal crusher (FW-100, Tianjin Taisite Instrument Co., Ltd, China) at a particle size of 0.125-mm sieve.

\subsection{Preparation of Biochar}

BSG and SS were mixed in various proportion (Table 1) then placed in ceramic crucibles, and pyrolyzed under oxygen-limited atmosphere in a muffle furnace (SX2-8-10, Longkou, China).

The pyrolysis temperature was raised to 400, 500, 600 and $700^{\circ} \mathrm{C}$ at a rate of approximately $50^{\circ} \mathrm{C}$ per $30 \mathrm{~min}$ and

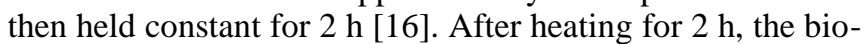
char samples were allowed to cool to room temperature. Three replicates were done for each proportion of BSG and SS during the bio-char generating process.

\subsection{Physical and Chemical Properties of the Biochar}

The biochar production rate was calculated using the following equation:

Production rate $(\%)=($ MBio-char/MRaw material $) \times$ 100, where MBio-char and MRaw material are the mass of the biochar and its feedstock, respectively.

The ash content of biochar was determined by calcining six hours in $750^{\circ} \mathrm{C}$ and the equation:

ash content $(\%)$

Where: $\mathrm{m} 1$ is the mass of crucible, $\mathrm{g} ; \mathrm{m} 2$ is the mass of biochar and crucible, $\mathrm{g} ; \mathrm{m} 3$ is the mass of ash and crucible, g.

Biochar $\mathrm{pH}$ measured by using a PHS-3C $\mathrm{pH}$ meter (Leici, China) at a 1:2.5 suspension in ultrapure water [17]. Biochar sample mixed with $\mathrm{KBr}$ in a ratio of $1: 100(\mathrm{w} / \mathrm{w})$ determined Fourier transform infrared (FT-IR) (IRPrestige21, Japan) at wave number ranging from 4000 to $500 \mathrm{~cm}^{-1}$. The surface structure of biochar was conducted by Scanning
Electron Microscope (SEM) (FEI Quanta-200, USA), and micrographs $(\times 2500)$ [18].

\subsection{Adsorption Experiments for Wastewater}

Batch experiments were conducted in $250 \mathrm{ml}$ conical flasks at room temperature $\left(25 \pm 1^{\circ} \mathrm{C}\right)$. Biochar $(10 \mathrm{~g})$ prepared with various proportion (Table 1) and various temperature (from $400^{\circ} \mathrm{C}$ to $700^{\circ} \mathrm{C}$ ) was added into the ammonium-nitrogen, phosphorus-containing, and chr0miumcontaining solution shaking at a speed of $80 \mathrm{rpm}$ in a mechanical shaker for $5 \mathrm{~h}$ and avoid light. The mixture was filtered through vacuum filtration to remove particles and then determined ammonium nitrogen $\left(\mathrm{NH}_{3}-\mathrm{N}\right)$, phosphorus and chromium (VI), respectively [19]. Each experiment was duplicate to ensure the credibility of the data. Variance between any duplicate measurements in this work was smaller than $5 \%$.

\section{RESULTS AND DISCUSSION}

\subsection{Biochar Yield}

As shown in Fig. (1), temperature was an important factor that affected the biochar yield. Biochar yield decreased markedly with the temperature increasing at the same SS proportion. Study showed that more organic matter turning into volatiles with the increasing final pyrolysis temperature, then biochar yield decreased [20]. Fig. (1) also showed that when the pyrolysis temperature was $400^{\circ} \mathrm{C}$ and $700^{\circ} \mathrm{C}$ the absolute value of curve slope were relatively small than others which indicated that the yield changed slightly. Under low temperature $\left(400^{\circ} \mathrm{C}\right)$ conditions, it had not reached strength that made biomass completely carbonized, and under high temperature $\left(700^{\circ} \mathrm{C}\right)$ conditions, the biomass had been completely carbonized, further increase the temperature the effect was not significant. The carbonization rates were obvious at temperature $500^{\circ} \mathrm{C}$ and $600^{\circ} \mathrm{C}$ which showed that this two temperature were the key temperature that the biomass carbonized.

Biochar yield increased significantly with the increase of $\mathrm{SS}$ addition proportion at the same temperature condition indicating that more SS proportion could produce more carbon contained materials. The contents of inorganic substances in the SS was far higher than those in BSG, so under the same temperature conditions, higher BSG proportion resulted in more organic matter burn in to fuel gas or oil.

Table 1. The proportion of brewery`s spent grain (BSG) and sewage sludge (SS)

\begin{tabular}{|c|c|c|c|c|c|c|}
\hline No. & $0 \#$ & $1 \#$ & $2 \#$ & $3 \#$ & $4 \#$ & $5 \#$ \\
\hline \hline Proportion of SS \% & 0 & 10 & 20 & 30 & 40 & 50 \\
\hline
\end{tabular}

(1-2)

\begin{tabular}{|c|c|c|c|c|c|}
\hline No. & $6^{\#}$ & $7^{\#}$ & $8^{\#}$ & $9^{\#}$ & $10^{\#}$ \\
\hline \hline Proportion of SS $\%$ & 60 & 70 & 80 & 90 & 100 \\
\hline
\end{tabular}




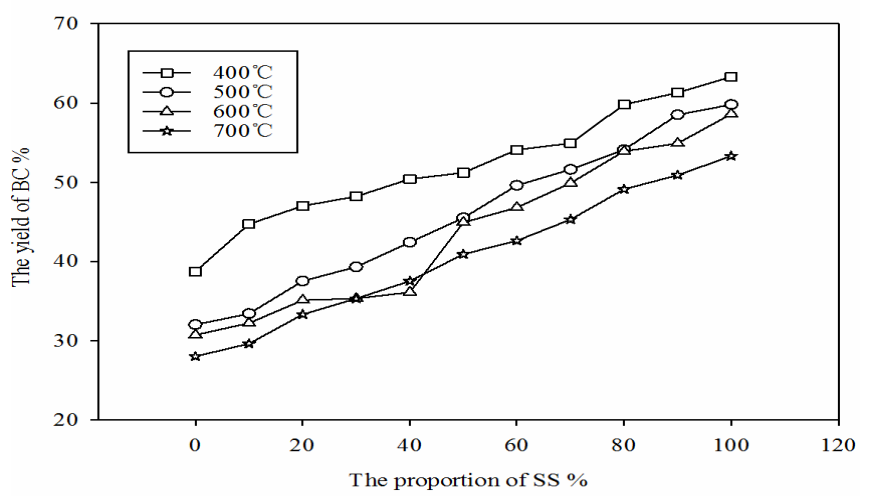

Fig. (1). The effect of pyrolysis temperature and the proportion of SS on the yield of biochar.

\subsection{Ash Content of Biochar}

Fig. (2) showed that the ash contents increased with the increasing pyrolysis temperature under the same proportion of SS conditions. $700^{\circ} \mathrm{C}$ was the highest ash contents followed $600^{\circ} \mathrm{C}>500^{\circ} \mathrm{C}>400^{\circ} \mathrm{C}$. The result indicated that with the increasing of pyrolysis temperature, the pyrolysis degree of biomass increased, then the biochar yield decline which ash contents accumulated gradually. Under the same temperature, more proportion of BSG lead to higher contents of ash which because BSG contained more $\mathrm{Si}$ and organic matter compared with SS.

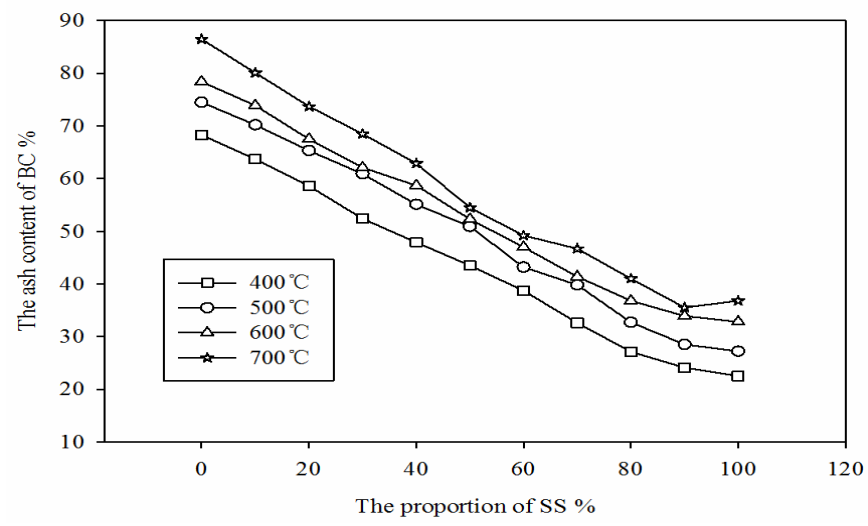

Fig. (2). The effect of pyrolysis temperature and the proportion of $\mathrm{SS}$ on the ash content of biochar.

\subsection{FT-IR}

It found that the increasing temperature and proportion of SS did not caused significant differences in the FT-IR spectra indicating that the biochar contained similar groups.

Fig. (3) showed that biochar samples was in rich of the surface oxygen containing functional groups such as carboxyl group $\left(3430 \mathrm{~cm}^{-1}\right)$, and aliphatic ether $\mathrm{C}=\mathrm{O}$ and alcohol C-O stretching $\left(1734 \mathrm{~cm}^{-1}\right.$ and $\left.1100 \mathrm{~cm}^{-1}\right)$. However, there was an alteration only at $400^{\circ} \mathrm{C}$, there was aliphatic $\mathrm{CH}_{2}$ stretching $\left(2920 \mathrm{~cm}^{-1}\right)$, and with the increasing pyrolysis temperature the alkyl eliminated and the degree of aromatization increased $[16,21]$.

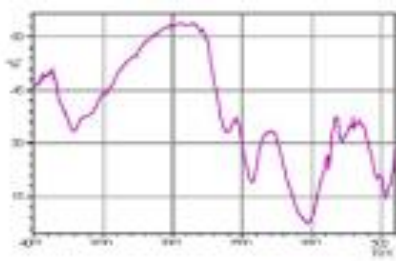

4030 SS peoportica 806 .

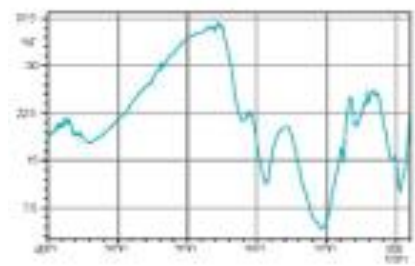

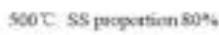

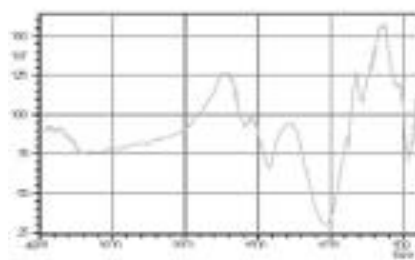

600 C SS proportion 80 s.

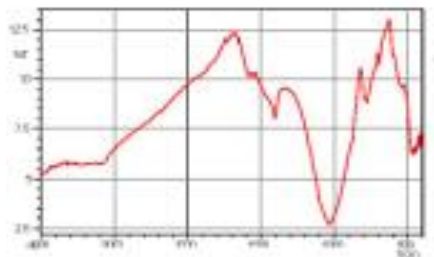

rose ss pregertion $80 \mathrm{~s}$

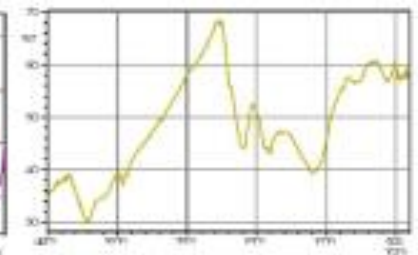

$400 \mathrm{C}$ SS propartion $20 \mathrm{si}$

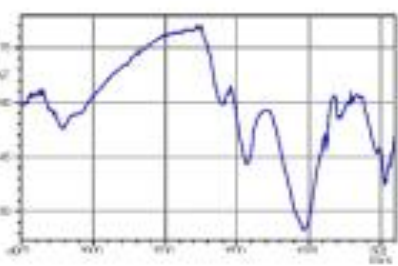

soor $\$ 8$ perportion $20 \mathrm{~s}$

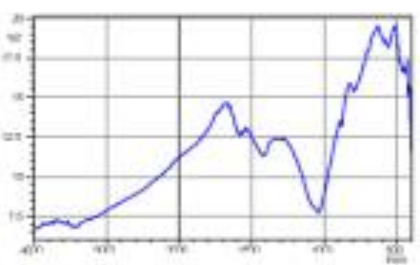

$6000 \mathrm{Cs}$ propontion $20 \mathrm{se}$

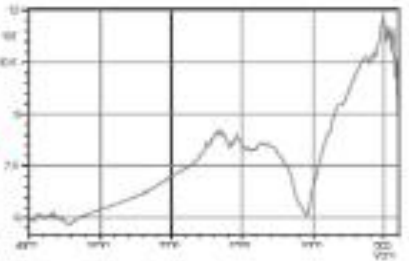

700088 proponion 804
Fig. (3). FTIR spectra of biochar prepared at different pyrolysis temperature of the proportion of SS $80 \%$ and $20 \%$.

\subsection{SEM}

SEM images are very useful to obtain accurate details about pore structure of biochar. From Fig. (4) the result demonstrated that biochar had some internal pores and cracks. Under the same proportion of SS conditions, with various pyrolysis temperature, the biochar surface had great difference. When the pyrolysis temperature was $400{ }^{\circ} \mathrm{C}$ there began to appear tubular structure, but no appreciable pore structures.

Furthermore, with the increasing pyrolysis temperature, the surface pore structure were more and more apparent, the pore size were more and more bigger, and the wall of the pore were more and more thinner. It was also found that there were more smaller pore appear on biochar surface when the temperature were $600^{\circ} \mathrm{C}$ and $700^{\circ} \mathrm{C}$. As known, with the increasing pyrolysis temperature, the organic matter in biomass consumed gradually which lead to pore structure on biochar surface becoming more and more obvious and developed more and smaller pore [22].

\section{5. $\mathrm{pH}$}

Fig. (5) showed that the $\mathrm{pH}$ values increased with the increasing proportion of $\mathrm{SS}$ in the same preparation 
temperature which because SS contained more $\mathrm{CaO}$ which was used in the sewage disposal process.
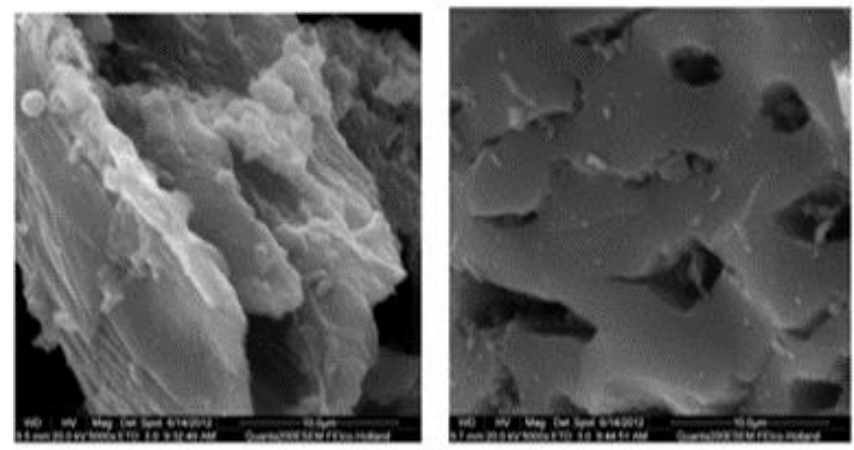

$400^{\circ} \mathrm{C}$ The propartion of SS $10 \%$ ( $\times 5000$ ) $500^{\circ} \mathrm{C}$ The proportion of $\mathrm{SS} 10 \%$ ( $\times 5000$ )
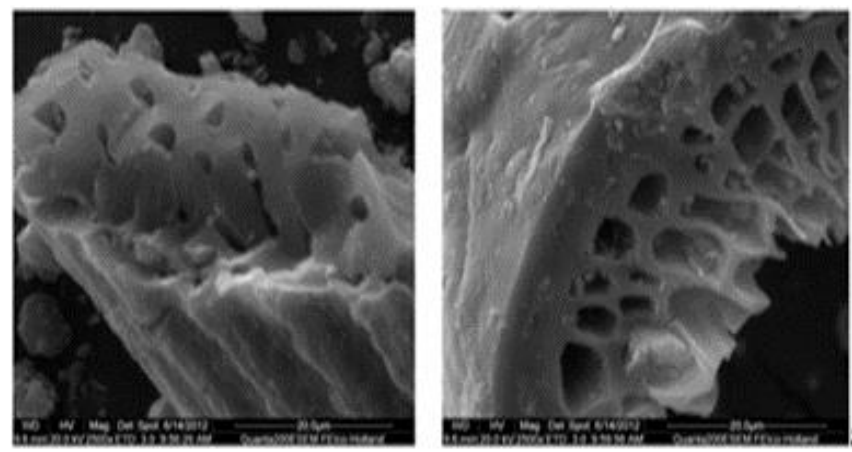

$600^{\circ} \mathrm{C}$ The proportion of SS $10 \%$ ( $\left.\times 2500\right) 700^{\circ} \mathrm{C}$ The proportion of SS $10 \%(\times 2500$ )

Fig. (4). SEM of biochar prepared at different pyrolysis temperature of the proportion of SS $10 \%$.

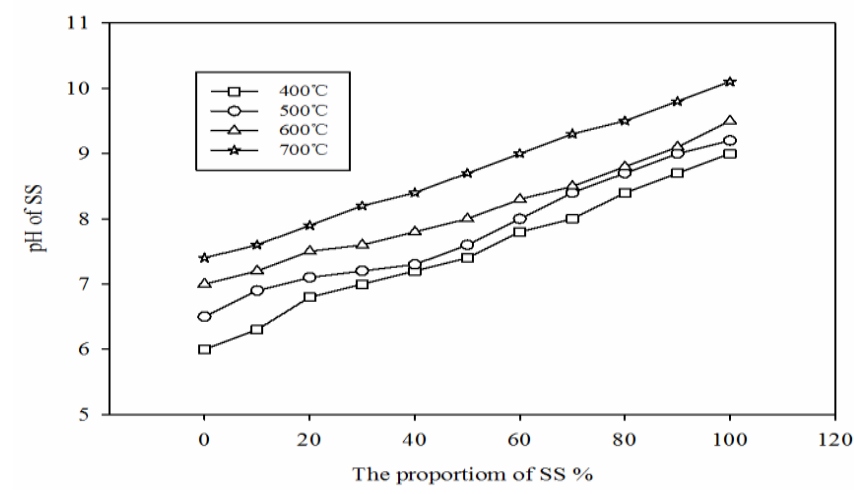

Fig. (5). The effect of pyrolysis temperature and the proportion of $\mathrm{SS}$ on $\mathrm{pH}$ of biochar.

Furthermore, in the same proportion of SS conditions, $\mathrm{pH}$ values increased with the increasing pyrolysis temperature. Due to ash contents accumulating with the increasing temperature, moreover, ash was alkaline [23], so $\mathrm{pH}$ values increased. However, $\mathrm{pH}$ values increased evidently at the temperature $400^{\circ} \mathrm{C}$ (pH from 6.0 to 9.0$)$ and $500^{\circ} \mathrm{C}(\mathrm{pH}$ from 6.5 to 9.2), on the contrary the change was slightly at the temperature $600^{\circ} \mathrm{C}(\mathrm{pH}$ from 7.0 to 9.5$)$ and $700^{\circ} \mathrm{C}(\mathrm{pH}$ from 7.4 to 10.1). Most of the biochar were alkaline which indicated that biochars contained alkaline matters.

\section{THE ADSORPTION OF WASTEWATER CHARAC- TERISTIC BY BIOCHAR}

\subsection{The Adsorption of Ammonia-Nitrogen Wastewater Characteristic by Biochar}

Fig. (6) showed the removal rate for ammonia-nitrogen by biochar. Result indicated that there was always an optimal proportion of SS (80\%) that preparation biochar for adsorption ammonia-nitrogen wastewater under the same temperature conditions.

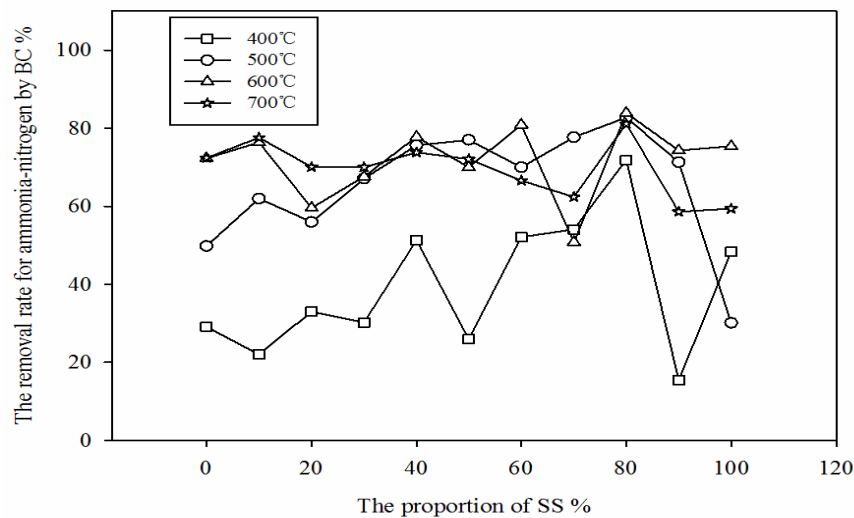

Fig. (6). The effect of pyrolysis temperature and the proportion of SS on the removal rate for ammonia-nitrogen of biochar.

Furthermore, as a whole, the biochar prepared under higher pyrolysis temperature $\left(600^{\circ} \mathrm{C}\right.$ and $\left.700^{\circ} \mathrm{C}\right)$ had better adsorption ability compared with low temperature $\left(400^{\circ} \mathrm{C}\right.$ and $\left.500^{\circ} \mathrm{C}\right)$. The removal rate ranged from $15.4 \%\left(400^{\circ} \mathrm{C}\right)$ to $81.1 \%\left(700^{\circ} \mathrm{C}\right)$. The result also shown that biochar had certain adsorption capacity for ammonia-nitrogen in wastewater which was consistent with that biochars had strong adsorption of $\mathrm{NH}_{4}^{+}$and $\mathrm{NO}_{3}^{-}$[24].

\subsection{The Adsorption of Phosphorus-Containing Wastewater Characteristic by Biochar}

Fig. (7) showed that biochar had complex effects on phosphorus adsorption. Biochar desorbed phosphorus into wastewater, when the preparation temperature was $400^{\circ} \mathrm{C}$, moreover, only a few proportion biochar were in adsorption state.

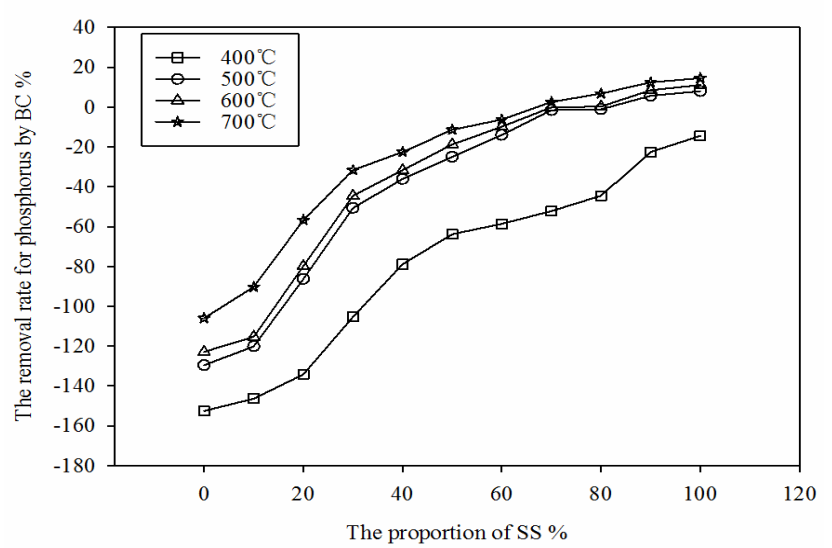

Fig. (7). The effect of pyrolysis temperature and the proportion of SS on the removal rate for phosphorus of biochar. 
This was mainly affected by $\mathrm{pH}$ value. High $\mathrm{pH}$ of biochar had better effect of adsorption phosphorus, and low $\mathrm{pH}$ was desorption effect. Many studies showed that $\mathrm{pH}$ affected adsorption of phosphorus was complicated. Song et $a l$. [25] indicated that the influence of $\mathrm{pH}$ on phosphorus was inverted "U" type; Liu et al. [26] showed that high $\mathrm{pH}$ was conducive to the adsorption of phosphorus. Furthermore, the adsorption effect was highest when the proportion of SS was $100 \%$ except $400^{\circ} \mathrm{C}$. Moreover, most of the biochars had desorption effect on phosphorus wastewater which demonstrated that the prepared biochars contained quite a part of phosphorus elements.

\subsection{The Adsorption of Chromium (VI)-containing Wastewater Characteristic by Biochar}

Fig. (8) showed that under same preparation temperature conditions, when the proportion of SS was $10 \%$, the removal rate of chromium (VI) was highest.

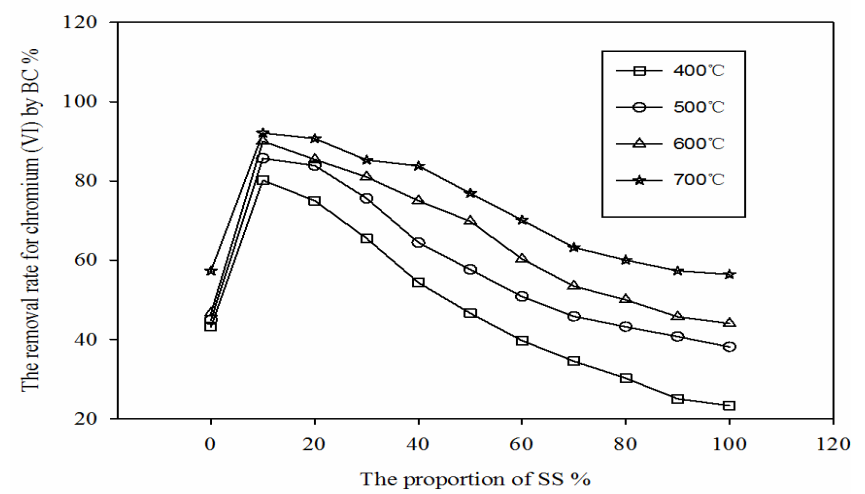

Fig. (8). The effect of pyrolysis temperature and the proportion of SS on the removal rate for chromium (VI) of biochar.

\section{CONCLUSION}

This work mixed BSG and SS together to produce biochar with various proportion and pyrolysis temperature. Mixing BSG and SS with various proportion was superior to the single raw materials producing biochar, and expand the BSG and SS utilization way. In order to evaluate the performance, biochar properties and adsorption characteristics was determined. Results showed that in the same pyrolysis temperature conditions, with the increasing proportion of SS, biochar yield and $\mathrm{pH}$ were increased, and ash content was decreased, but FT-TR had no significant change. However, in same SS proportion conditions, with the increasing pyrolysis temperature, the biochar $\mathrm{pH}$, ash content, the degree of aromatization, and number of holes were increased, but the yield was decreased. Adsorption results indicated that under same SS proportion conditions, with the increasing temperature, adsorption property for ammonianitrogen, phosphorus and chromium (VI) increased. Whereas, under same pyrolysis temperature, the best adsorption SS proportion for ammonia-nitrogen was $80 \%$, for phosphorus was $100 \%$, for chromium (VI) was $10 \%$.

\section{CONFLICT OF INTEREST}

The author confirms that this article content has no conflict of interest.

\section{ACKNOWLEDGEMENTS}

Declared none.

\section{REFERENCES}

[1] N. Chen, M. Wu, F. Xu, H.H. Chen, Z.N. Wang, X.L. Song, D. Zhang, P. Ning, B. Pan, "Sorption and desorption of phenanthrene in the biochar derived from Dianchi sediment", Environmental Chemistry, vol. 30, pp. 2026-2031, 2011.

[2] W.F. Liu, "Sorption Mechanisms of Diuron and Phenanthrene Onto Soil and Carbon Adsorbent and Study of Their Bioavailability", Beijing Jiaotong University, 2011.

[3] P. Zhang, J.Y. Wu, L. Li, Y. Liu, H.W. Sun, T.H. Sun, "Sorption and catalytic hydrolysis on carbaryl on pig-manure-derived biochars", Journal of Agro-Environment Science, vol. 31, pp. 416421, 2012.

[4] S. Öztürk, Ö. Özboy, İ. Cavidoğlu, H. Köksel, "Effects of brewer's spent grain on the quality and dietary fibre content of cookies", Journal of the Institute of Brewing, vol. 108, pp. 23-27, 2002.

[5] G. Zanker, W, Kepplinger. "The utilization of spent grains in the brewery integrated system", Brauwelt, vol. 142, pp. 1742-1747, 2002.

[6] H. Okamoto, K. Sato, N. Yagi, M. Inoue, S. Yamasaki, S. Ishid, J Shibata. "Development of production process of charcoal bricks from spent grain", Kagaku Kogaku Ronbunshu, , vol. 28, pp. 137167, 2002.

[7] W. Russ, H. Mörtel, R. Meyer-Pittroff, "Application of spent grains to increase porosity in bricks", Construction and Building Materials, vol. 19. pp. 117-126, 2005.

[8] N. Ishiwaki, H. Murayama, H. Awayama, O. Kanauchi, T. Sato, "Development of high value uses of spent grain by fractionation technology", Technical quarterly-Master Brewers Association of the Americas, vol. 37, pp. 261-265, 2000.

[9] J.J. Manyà, "Pyrolysis for Biochar Purposes: A Review to Establish Current Knowledge Gaps and Research Needs", Environmental Science and Technology, vol. 46, pp. 7939-7954, 2012,

[10] Lehmann and Joseph. Biochar for Environmental Management Science and Technology. Earthscan, UK: London, 2009

[11] B. Liang, J. Lehmann, D. Solomon, J. Kinyangi, J. Grossman, B. O'neill, J.O. Skjemstad, J. Thies, F.J. Luizao, J. Petersen, "Black carbon increases cation exchange capacity in soils", Soil Science Society of America Journal, vol. 70, pp. 1719-1730, 2006.

[12] B.L. Chen, D.D. Zhou, L.Z. Zhu, "Transitional adsorption and partition of nonpolar and polar aromatic contaminants by biochars of pine needles with different pyrolytic temperatures", Environmental Science and Technology, vol. 42, pp. 5137-5143, 2008.

[13] N.H. Hsu, L.S. Wang, Y.C. Lin, "Reduction of $\mathrm{Cr}(\mathrm{VI})$ by cropresidue-derived black carbon", Environmental Science and Technology, vol. 43, pp. 8801-8806, 2009.

[14] Z.G. Liu, F.S. Zhang, "Removal of lead from water using biochars prepared from hydrothermal liquefaction of biomass", Journal of Hazardous Materials, vol. 167, pp. 933-939, 2009.

[15] X.D. Cao, L.N. Ma, B. Gao, W. Harris, "Dairy-manure derived biochar effectively sorbs lead and atrazine", Environmental Science and Technology, vol. 43, pp. 3285-3291, 2009.

[16] Y. Chun, G.Y. Sheng, C.T. Chiou, B.S. Xing, "Compositions and sorptive properties of crop residue-derived chars", Environmental Science and Technology", vol. 38, pp. 4649-4655, 2004.

[17] R.K.Lu, "The Analysis Method of Soil Agricultural Chemistry (Eds The Chinese Society of Soil Science)", China Agricultural Science and Technology Press: Beijing, 2000.

[18] D. Özçimen, A.Ersoy-Meriçboyu, "Characterization of biochar and bio-oil samples obtained from carbonization of various biomass material", Renewable Energy, vol. 35, pp. 1319-1324, 2010. 
[19] Ministry of Environmental Protection of the People`s Republic of China, Water and Wastewater Monitoring Analysis Method, China Environmental Science Press, pp. 157-159, 252-258, 280-285, 2002.

[20] O. Mašek, P. Brownsort, A. Cross, S. Sohi, "Influence of production conditions on the yield and environmental stability of biochar", Fuel, vol. 103, pp.151-155, 2013.

[21] D. Mohan, C.U. Pittman, P.H. Steele, "Pyrolysis of wood/biomass for bio-oil: a critical review", Energy and Fuels, vol. 20, pp. 848889, 2006.

[22] H. Haykırı-Açma, A. Ersoy-Meriçboyu, S. Küçükbayrak, "Effect of mineral matter of the reactivity of lignite chars", Energy Conversion and Management, vol. 42, pp. 11-20, 2001.
[23] A. Proctor, S. Palaniappan, "Adsorption of soy oil free fatty acids by rice hull ash", Journal of the American Oil Chemists Society, vol. 67, pp. 15-17, 1990.

[24] Y. Li, F.M. Li, X.W. Zhang, Z.F. Wu, H. Yu, "Effects of biochar covering on the release of pollutants from sediment", Environmental Science, vol. 34, pp. 3071-3078, 2013.

[25] J.M. Song, "Transformable phosphorus in sediments adjacent to Yellow River estuary waters", Marine Science, vol. 24, pp. 42-45, 2000.

[26] H.Y. Liu, X.G. Zhou, X.Y. Ma, S.B. Guo, "Impact of $\mathrm{pH}$ value on phosphorus adsorption of sediment in Huang River", Environmental Science of Inner Mongolia, vol. 19, pp. 72-74, 2007.

(C) Yinxin et al.; Licensee Bentham Open.

This is an open access article licensed under the terms of the Creative Commons Attribution Non-Commercial License (http://creativecommons.org/licenses/by-nc/3.0/) which permits unrestricted, non-commercial use, distribution and reproduction in any medium, provided the work is properly cited. 